\title{
Analisis Budaya Organisasi dan Iklim Organisasi Untuk Meningkatkan Kinerja Karyawan
}

\author{
Ripda Erwin \\ Program Studi Manajemen STIE Trisna Negara Belitang Sumsel \\ email : ripdaerwin@gmail.com
}

\begin{abstract}
ABSTRAK
Tujuan penelitian ini untuk mengetahui pengaruh budaya organisasi dan iklim organisasi terhadap kinerja karyawan pada PT. Samudra Muara Enim Sumatera Selatan. Populasi dalam penelitian ini adalah seluruh karyawan pada PT. Samudra Muara Enim Sumatera Selatan berjumlah 31 orang dan sekaligus diambil sebagai sampel penelitian. Metode pengumpulan data menggunakan kuesioner dan dokumentasi. Teknik analisis yang digunakan dalam penelitian ini adalah uji validitas dan reliabilitas instrumen, uji asumsi klasik, analisis regresi linier berganda, analisis korelasi, analisis determinasi, uji F dan uji t dengan bantuan software SPSS 22.0 for windows.

Hasil penelitian menunjukkan bahwa: 1) Secara bersama-sama terdapat pengaruh signifikan budaya organisasi dan iklim organisasi terhadap kinerja karyawan pada PT. Samudra Muara Enim Sumatera Selatan. 2) Secara parsial terdapat pengaruh positif dan signifikan budaya organisasi terhadap kinerja karyawan pada PT. Samudra Muara Enim Sumatera Selatan. 3) Ssecara parsial terdapat pengaruh positif dan signifikan iklim organisasi terhadap kinerja karyawan pada PT. Samudra Muara Enim Sumatera Selatan.
\end{abstract}

Kata kunci : Budaya Organisasi, iklim organisasi dan kinerja karyawan

\begin{abstract}
The purpose of this study to determine the influence of organizational culture and organizational climate on employee performance at PT. Samudra Muara Enim South Sumatra. Population in this research is all employees at PT. Ocean Muara Enim Sumatera Selatan totaling 31 people and also taken as sample of research. Methods of data collection using questionnaires and documentation. The analysis technique used in this research is validity and reliability test of instrument, classical assumption test, multiple linear regression analysis, correlation analysis, determination analysis, $F$ test and $t$ test with SPSS 22.0 for windows software.

The results showed that: 1) Collectively there is significant influence of organizational culture and organizational climate on employee performance at PT. Samudra Muara Enim South Sumatra. 2) Partially there is positive influence and significant organizational culture on employee performance at PT. Samudra Muara Enim South Sumatra. 3) Partially there is a positive influence and significant organizational climate on employee performance at PT. Samudra Muara Enim South Sumatra.
\end{abstract}

\section{Keywords: Organizational Culture, organizational climate and employee performance}

\section{PENDAHULUAN}

Organisasi mencerminkan adanya kerja sama antara beberapa orang yang membentuk kelompok atau kerja sama dengan maksud mencapai tujuan yang telah disepakati. Organisasi dapat terbentuk karena dipengaruhi oleh beberapa aspek seperti penyatuan visi dan misi serta tujuan yang sama dengan perwujudan eksistensi sekelompok orang terhadap masyarakat.

Budaya organisasi merupakan perangkat sistem nilai, keyakinan, asumsi atau norma yang telah lama berlaku, disepakati dan diikuti oleh para anggota suatu organisasi sebagai 
pedoman perilaku dan pemecahan masalah-masalah dalam organisasi.

Sedangkan iklim organisasi mempengaruhi peraktik dan kebijakan SDM yang diterima oleh anggota organisasi. Perlu diketahui bahwa setiap organisasi akan memiliki iklim organisasi yang berbeda. Keanekaragaman pekerjaan yang dirancang didalam organisasi, atau sifat individu yang ada akan menggambarkan perbedaaan tersebut. Iklim organisasi yang terbuka akan memacu karyawan untuk mengutarakan kepentingan dan ketidakpuasan tanpa adanya rasa takut akan tindakan balasan dan perhatian. Ketidakpuasan seperti itu dapat ditangani dengan cara yang positif dan bijaksana. Iklim keterbukaan, bagaimanapun juga hanya tercipta jika semua anggota memiliki tingkat keyakinan yang tinggi dan mempercayai keadilan tindakan.

Dikehidupan sekarang ini yang semakin kompleks dan kompetitif membuat kinerja pegawai akan semakin optimal dengan budaya organisasi dan iklim organisasi yang makin kondusif. Budaya organisasi dan iklim organisasi yang kondusif dapat membuat pegawai lebih termotivasi untuk meningkatkan kualitas kinerjanya. Kinerja pegawai merupakan hasil kinerja yang dapat dicapai oleh seorang atau sekelompok pegawai dalam suatu organisasi (instansi) sesuai dengan wewenang dan tanggung jawabnya. Memang harus diakui bahwa kinerja seorang pegawai dipengaruhi oleh beberapa faktor internal, misalnya motivasi, kepuasan kerja, kesejahteraan, dan sebagainya. Namun keberadaan faktor internal tersebut tidak memiliki efek yang besar apabila kondisi eksternal pegawai dalam arti kondisi kelembagaan kurang baik dan tidak kondusif dengan demikian budaya organisasi yang merupakan gambaran persepsi dari perilaku organisasi sangat menentukan bagaimana pegawai memaksimalkan kinerjanya.

Iklim organisasi melukiskan lingkungan internal organisasi dan berakar pada budaya organisasi. Jika budaya organisasi relatif bersifat tetap dalam jangka panjang, iklim organisasi bersifat relatif sementara dan dapat berubah dengan cepat. Umumnya, iklim organisasi dengan mudah dapat dikontrol oleh pimpinan atau manajer. Iklim organsiasi merupakan persepsi anggota organisasi mengenai dimensidimensi iklim organisai. Iklim organisasi memengaruhi prilaku anggota organisasi kemudian memengaruhi kinerja mereka dan kemudian memengaruhi kinerja organsiasi.

Jika penerapan budaya organisasi dapat memengaruhi prilaku organisasi secara positif, maka pengaruh iklim organisasi terhadap prilaku organisasi dapat bersifat positif dan dapat bersifat negative. Misalnya, ruang kerja yang tidak baik, hubungan atasan dan bawahan yang konflik, dan birokrasi yang kaku dapat menimbulkan sikap negatif, stres kerja tinggi, serta motivasi dan kepuasan kerja yang rendah. Iklim organsiasi yang seperti ini akan menciptakan kinerja anggota organisasi rendah. Sebaliknya jika karyawan bekerja diruangan yang nyaman dan bersih, hubungan atasan dan bawahan yang kondusif dan birokrasi yang longgar akan menimbulkan sikap yang positif, stres kerja rendah, serta motivasi dan kepuasan kerja yang tinggi. Dari sini akan tercipta kinerja karyawan yang tinggi.

Dari hasil pengamatan penulis pada objek yang penulis teliti seorang pegawai dalam melakukan suatu pekerjaan belum memiliki kinerja yang tinggi, sebagian karyawan masih 
memiliki kinerja yang rendah walaupun telah banyak memiliki pengalaman kerja dan lembagapun telah banyak melakukan pelatihan maupun pengembangan terhadap sumberdaya manusianya untuk dapat meningkatkan kemampuan dan motovasi kerja pegawainya. Selain itu dari pengamatan peneliti kurangnya tanggung jawab pegawai pada bidang pekerjaannya sehingga sering adanya rekan kerja yang suka membebankan tugasnya pada rekannya. Dan juga sering terjadinya rolling ruang kerja dimana para pegawai belum menguasai pekerjaan baru mereka. Kinerja karyawan yang rendah akan menjadi suatu permasalahan bagi suatu organisasi atau lembaga, karena kinerja yang dihasilkan karyawan tidak sesuai dengan yang diharapkan oleh organisasi.

Berdasarkan latar belakang di atas penelitian ini bertujuan untuk mengetahui pengaruh Budaya Organisasi dan Iklim Organisasi terhadap Kinerja Karyawan. Permasalahan dalam penelitian ini adalah apakah ada pengaruh Budaya Organisasi dan Iklim Organisasi terhadap Kinerja Karyawan.

Dari latar belakang diatas, penulis melakukan penelitian dengan judul : "Analisis Budaya Organisasi dan Iklim Organisasi untuk Meningkatan Kinerja Karyawan Pada PT. Samudra Muara Enim Sumatera Selatan.

\section{TINJAUAN PUSTAKA Budaya Organisasi}

Menurut Surtisno (2013: 2), budaya organisasi dapat didefinisikan sebagai perangkat sistem nilai-nilai, keyakinan-keyakinan, asumsi-asumsi, atau norma-norma yang telah lama berlaku, disepakati dan diikuti oleh para anggota suatu organisasi sebagai pedoman perilaku dan pemecahan masalah-masalah organisasinya. Budaya organisasi merupakan suatu kekuatan sosial yang tidak tampak, yang dapat menggerakkan orangorang dalam suatu organisasi untuk melakukan aktivitas kerja.

Menurut Una

(2015:4), mendefinisikan bahwa budaya organisasi adalah nilai-nilai yang menjadi pegangan sumber daya manusia dalam menjalankan kewajiban dan perilaku didalam organisasi. Budaya organisasi dalam disiplin keilmuan masih tergolong baru, sebenarnya sudah ada sejak pertengahan abad kedua puluh.

Selanjutnya Schein dalam Tika (2010:77) mengatakan bahwa budaya organisasi sebagai pola asumsi dasar yang telah dikemukakan oleh suatu kelompok tertentu, ditemukan atau dikembangkan untuk mempelajari cara mengatasi masalah-masalah adaptasi dari luar dan cara berintegrasi, yang telah berfungsi dengan baik untuk dianggap berlaku, dan karena itu, harus diajarkan kepada anggota baru sebagai cara yang benar untuk memandang, memikirkan dan merasakan masalah-masalah lain.

Berdasarkan pendapat-pendapat tersebut, dapat disimpulkan bahwa budaya organisasi sebagai suatu sistem nilai (apa yang penting) dan keyakinan (bagaimana segala sesuatunya berfungsi) yang berinteraksi dengan orang-orang, srtuktur organisasi dan sistem pengendalian dalam perusahaan tersebut ditemukan atau dikembangkan untuk mempelajari cara mengatasi masalah-masalah. Dengan indikator yaitu Kepatuhan terhadap prosedur kerja, Kepatuhan terhadap jam kerja dan Kepatuhan terhadap perintah atasan. 


\section{Iklim Organisasi}

Wirawan (2008 : 122) Iklim Organisasi adalah persepsi anggota organisasi (secara individual dan kelompok) dan mereka yang secara tetap berhubungan dengan organisasi (misalnya pemasok, konsumen, konsultan, dan kontraktor) mengenai apa yang ada ataudilingkungan internal lingkungan organisasi secara rutin, yang mempemgaruhi sikap dan perilaku organisasi dan kinerja anggota organisasi yang kemudian menentukan kinerja organisasi.

Iklim organisasi secara objektif eksis, (Wirawan,2008: 128), terjadi disetiap organisasi, dan mempengaruhi prilaku anggota organisasi, tetapi ahnay dapat diukur secara tidak langsung melalui persepsi anggota organisasi

Menurut Sofyandi (2012) iklim suatu organisasi merujuk pada berfungsinya organisasi secara keseluruhan dari sudut pandang para karyawan. Dengan demikian, iklim adalah suatu metafora yang menggambarkan agregat persepsi karyawan individual mengenai lingkungan organisasi mereka. Dimensi-dimensi tertentu dari iklim memberikan pengaruh khusus pada kemampuan organisasi untuk meningkatkan kinerja mereka. Dimensi iklim organisasi dalam penelitian adalah Keadaan lingkungan fisik, Keadaan lingkungan sosial, Pelaksanaan sistem manajemen, Produk, Konsumen yang dilayani, Kondisi fisik dan kejiwaan anggota organisasi dan Budaya organisasi.

\section{Kinerja Karyawan}

Dalam kajian manajemen, pengertian kinerja (performance) didefinikan secara beragam oleh para ahli namun substansinya sama yaitu suatu output yang di hasilkan melalui prestasi kerja. Wibowo (2014: 7)
Kinerja berasal dari pengertian performance. Ada pula yang memberikan pengertian permormance sebagai hasil kerja atau prestasi kerja. Namun, sebenernya kinerja mempunyai makna yang lebih luas, bukan hanya hasil kerja, tetapi termasuk bagaimana proses pekerjaan berlangsung.

Menurut Mangkunegara dalam Pramudyo, (2010) prestasi kerja berasal dari kata job performance atau actual performance yaitu hasil kerja secara kualitas dan kuantitas yang dicapai oleh seorang pegawai dalam melaksanakan tugasnya sesuai dengan tanggung jawab yang diberikan kepadanya.

Bangun mendefinisikan kinerja adalah hasil pekerjaan yang dicapai seseorang bedasarkan persyaratan-persyaratan pekerjaan. Kinerja pegawai memenuhi seberapa banyak mereka memberikan kontribusi kepada organisasi.

Dengan demikian dapat disimpulkan bahwa kinerja merupakan suatu hasil kerja yang dicapai seseorang dengan membandingkan hasil kerja yang telah dilakukan terdahulu dan sering dilakukan sekarang. Dengan indikator Jumlah pekerjaan, kualitas pekerjaan, ketepatan waktu, kehadiran dan kemampuan kerja sama.

\section{METODE PENELITIAN}

Metode penelitian yang digunakan dalam penelitian ini adalah explanatory research. Peneliti menggunakan explanatory research, karena penelitian ini mempunyai tujuan mengunji hipotesis untuk mengetahui ada tidaknya hubungan antara variabel independen yaitu budaya organisasi, dengan variabel dependen yaitu kinerja dosen. Berdasarkan metode tersebut, peneliti menggunakan pendekatan kuantitatif 
untuk menguji suatu konsep atau teori sehingga dapat dirumuskan hipotesis, untuk menyajikan suatu fakta atau mendeskripsikan statistik, untuk menunjukan hubungan di antara dua variabel. Populasi dalam penelitian ini adalah pegawai PT. Samudra Muara Enim berjumlah 31 orang dan metode sampling yang digunakan adalah metode sensus dengan jumlah responden sebanyak 31 orang.

Sumber data yang digunakan pada penelitian ini adalah data primer dan data sekunder. Data primer merupakan data yang diperoleh langsung dari objek penelitian yaitu dari hasil penyebaran kuesioner dan wawancara kepada pegawai PT. Samudra Muara Enim. Data sekunder dalam penelitian ini adalah laporan penelitian, buku, web dan juga jurnaljurnal yang terkait dengan budaya organisasi, iklim organisasi, dan kinerja karyawan. Penelitian ini menggunakan alat analisis berupa uji validitas, uji reliabilitas, analisa regresi linier berganda, uji $t$, uji $F$ dan koefisien determinasi.

\section{HASIL DAN PEMBAHASAN}

\section{Uji Kualitas Data}

Uji Validitas dan Reliabilitas

Berdasarkan hasil uji validitas diperoleh nilai $r_{\text {hitung }}$ untuk variabel budaya organisasi berada diantara 0,458-0,787. Untuk variabel iklim organisasi berada diantara 0,4870,850 . Sedangkan variabel kinerja karyawan berada diantara 0,3810,810 . Nilai $r_{\text {hitung }}$ tersebut lebih besar dari $r_{\text {tabel }}(0,355)$. Dengan demikian dapat disimpulkan bahwa setiap butir pertanyaan adalah valid. Hal ini berarti bahwa semua butir yang dijadikan sebagai indikator terhadap variabel budaya organisasi, iklim organisasi dan kinerja karyawan telah sah untuk dijadikan sebagai alat ukur dalam penelitian ini.

Hasil uji reliabilitas menunjukkan bahwa untuk variabel budaya organisasi, iklim organisasi dan kinerja karyawan memiliki nilai masing-masing sebesar $(0,778,0,887$ dan 0,800$)$ mempunyai koefisien Alpha diatas 0,6 sehingga dapat dikatakan konsep pengukur variabel dari kuesioner adalah reliabel yang berarti bahwa kuesioner yang digunakan dalam penelitian ini merupakan kuesioner yang handal.

\section{Uji Asumsi Klasik}

Uji Normalitas

Tabel 1. Hasil Uji Normalitas

\begin{tabular}{lc}
\hline \multicolumn{1}{c}{$\begin{array}{c}\text { Variabel } \\
\text { Independen }\end{array}$} & $\begin{array}{c}\text { Asymp Sig. } \\
\text { (2-Tailed) }\end{array}$ \\
\hline Budaya Organisasi & 0.445 \\
Iklim Organisasi & 0.219 \\
Kinerja Karyawan & 0.800 \\
\hline Sumber : Data primer yang diolah 2017 \\
\multicolumn{3}{c}{ Berdasarkan hasil uji normalitas } \\
data menggunakan One Sample \\
Kolmogorov Smirnov Test, \\
sebagaimana tersaji pada tabel dapat \\
disimpulkan bahwa semua variabel \\
memiliki data normal, hal tersebut \\
dikarenakan data tersebut memiliki \\
Asymp. Sig $>$ (a) $0,05$.
\end{tabular}

Uji Multikolonearitas

Tabel 2. Hasil Uji Multikolinearitas

\begin{tabular}{|c|c|c|}
\hline \multirow[t]{2}{*}{ Model } & \multicolumn{2}{|c|}{ Collinearity Statistics } \\
\hline & Tolerance & VIF \\
\hline Budaya Organisasi & .569 & 1.756 \\
\hline Iklim Organisasi & .569 & 1.756 \\
\hline
\end{tabular}

Sumber : Data primer yang diolah 2017

Pada output SPSS pada tabel diatas menunjukkan semua angka VIF variabel model regresi lebih kecil dari 5 (VIF < 5), hal ini menunjukkan model regresi linier berganda tidak mempunyai persoalan multikolinearitas. Hasil perhitungan nilai tolerance juga menunjukkan tidak 
ada varibel independen yang nilainya kurang dari 0,1 (tolerance $<0,1$ ), yang berarti tidak ada korelasi antar variabel independen yang nilainya lebih dari $95 \%$, hal ini berarti tidak terjadi multikolinearitas.

Uji Heteroskedastisitas

Tabel 3. Hasil Uji Heterokedastisitas

\begin{tabular}{lc}
\hline $\begin{array}{c}\text { Variabel } \\
\text { Independen }\end{array}$ & $\begin{array}{c}\text { Unstandardized } \\
\text { Residual } \\
\text { Sig. (2-Tailed) }\end{array}$ \\
\hline Budaya Organisasi & 0.514 \\
Iklim Organisasi & 0.515 \\
\hline
\end{tabular}

Sumber : Data primer yang diolah 2017
Berdasarkan hasil uji heteroskedastisitas dengan menggunakan uji koefisien korelasi spearman's rho dapat dilihat bahwa korelasi antara variabel bebas (budaya organisasi dan iklim organisasi) dengan unstandardized residual (ABS_RES) memiliki nilai signifikan lebih dari 0,05. Karena signifikansi lebih besar daripada 0,05, maka dapat disimpulkan bahwa tidak terdapat gejala heteroskedasitas.

\section{Metode Analisis Data}

Tabel 4. Rekapitulasi Hasil Uji Regresi

\begin{tabular}{lccccc}
\hline \hline \multicolumn{1}{c}{ Variabel Bebas } & $\begin{array}{c}\text { Koefisien } \\
\text { Regresi (B) }\end{array}$ & Beta & $\mathbf{t}$ & $\begin{array}{c}\text { Probabilitas } \\
\text { (Sig t) }\end{array}$ & $\begin{array}{c}\text { Keputusan } \\
\text { Terhadap Ha }\end{array}$ \\
\hline Constant & 0.874 & & 1.676 & 0.105 & \\
Budaya Organisasi $\left(\mathrm{X}_{1}\right)$ & 0.341 & 0.328 & 2.148 & 0.041 & Diterima \\
Iklim Organisasi $\left(\mathrm{X}_{2}\right)$ & 0.477 & 0.537 & 3.519 & 0.002 & Diterima \\
\hline$F_{\text {tabel }}$ & $=3.30$ & & & & \\
Fnhitung & $=23.627$ & & & & \\
Sig. F & $=0.000$ & & & & \\
ttabel & $=2.039$ & & & & \\
R & $=0.792$ & & & & \\
Adjusted R Square & $=0.601$ & & &
\end{tabular}

Sumber : Data primer yang diolah 2017

\section{Analisis Regresi Berganda}

Model persamaan regresi yang dapat dituliskan dari hasil tersebut dalam bentuk persamaan regresi standardized adalah sebagai berikut :

$$
\dot{Y}=0,874+0,341 X_{1}+0,477 X_{2}
$$

Dari persamaan tersebut dapat terlihat bahwa keseluruhan variabel bebas (budaya organisasi dan iklim organisasi) berpengaruh positif terhadap kinerja karyawan. Berdasarkan persamaan dapat diketahui bahwa variabel bebas yang paling berpengaruh adalah variabel iklim organisasi dengan koefisien beta 0,537 , kemudian diikuti oleh variabel budaya organisasi dengan koefisien beta 0,328 .

\section{Analisis Koefisien Korelasi (R) dan Determinasi $\left(\mathbf{R}^{2}\right)$}

Dari hasil pengujian diatas diperoleh nilai $R$ sebesar 0,792 berarti hubungan budaya organisasi dan iklim organisasi terhadap kinerja karyawan kuat. Maksudnya jika ada peningkatan hubungan budaya organisasi dan iklim organisasi maka diikuti juga dengan peningkatan kinerja karyawan, begitu pula sebaliknya. Untuk nilai Adjusted $R$ Square $\left(R^{2}\right)$ sebesar 0,601 , hal ini berarti hubungan budaya organisasi dan iklim organisasi memberikan sumbangan sebesar $60,1 \%$ terhadap kinerja karyawan (Y) sedangkan sisanya 39,9\% dipengaruhi oleh faktor lain yang tidak diteliti. 


\section{Uji Hipotesis \\ Uji F (Simultan)}

Hasil pengujian pada tabel (ANOVA) diperoleh nilai $\mathrm{F}_{\text {hitung }}$ sebesar 23,627 dan $F_{\text {tabel }}$ sebesar 3.30 (23.627 $>3.30$ ) atau dengan menggunakan taraf signifikan yaitu nilai sig. sebesar 0,000 (sig $F=0,000<\alpha 0.05$ ). Jadi dapat disimpulkan bahwa Ho ditolak $\mathrm{Ha}$ diterima, artinya secara simultan/bersama-sama terdapat pengaruh yang signifikan antara budaya organisasi dan iklim organisasi terhadap kinerja karyawan.

Kinerja dalam perusahaan modern saat ini perlu mendapatkan perhatian dalam mengelolanya. Apabila kinerja karyawan dalam suatu perusahaan tidak ditata dengan baik maka akan dapat menjadi salah satu penghambat aktivitas perusahaan dalam mencapai tujuannya. Penataan kinerja ini tentunya juga memerlukan penyesuaian kondisi atau keadaan perusahaan agar sanggup bersaing dengan perusahaan lain dalam era globalisasi saat ini.

Maka dapat disimpulkan bahwa Iklim organisasi dan budaya organisasi merupakanfaktor yang penting dalam meningkatkan kinerja karyawan didalamnya. Perusahaan yang memiliki iklim organisasi dan budaya organisasi yang kuat akan berdampak baik pada kinerja karyawannya. Pihak perusahaan harus senantiasa mengontrol perilaku karyawannya sehingga karakteristik perusahaan tetap terjaga dan kinerja karyawan akan meningkat untuk menunjang proses pencapaian tujuan-tujuan perusahaan.

\section{Uji t (Parsial)}

\section{Pengaruh Budaya Organisasi terhadap Kinerja Karyawan}

Berdasarkan tabel 4 dapat dilihat bahwa nilai koefisien variabel budaya organisasi menunjukkan angka positif yaitu sebesar 0.341 dan nilai signifikan sebesar 0,041 nilai ini lebih kecil dari alpha $5 \%(0,041<0,05)$. Hal ini menunjukan Ho ditolak $\mathrm{Ha}$ diterima, artinya secara parsial terdapat pengaruh positif dan signifikan budaya organisasi terhadap kinerja karyawan.

Penelitian ini sesuai dengan penelitian yang dilakukan oleh Amanda, Enno Aldea dkk (2017), Novziransyah, Nanda (2017), Radianto, Ari \& Bambang Swasto Sunuharyo (2017) dan Zahriyah, Umi Wita, dkk (2015) menemukan bahwa terdapat pengaruh budaya organisasi terhadap kinerja karyawan.

Penelitian ini juga diperkuat oleh pendapat Deal \& Kennedy (1982), Miner (1990), Robbins (1990) dalam Sutrisno, (2013:3) bahwa budaya organisasi yang kuat sangat berpengaruh terhadap efektivitas kinerja karyawan. Jika budaya organisasi di suatu perusahaan itu kuat maka kinerja karyawan didalamnya akan meningkat, dan sebaliknya jika budaya organisasi diperusahaan itu lemah maka akan berpengaruh pada kinerja karyawan yang akan terus menurun.

Budaya organisasi secara sistematis akan menuntun semua karyawan yang ada didalam perusahaan agar dapat meningkatkan kinerjanya secara maksimal. Suatu organisasi dirasa perlu memperhitungkan budaya organisasi yang kuat dan sejalan dengan beberapa batasanbatasan yang berlaku. Selama memiliki budaya organisasi yang kuat, berdampak baik dan dapat diterapkan dengan baik oleh anggota organisasi tersebut maka dapat memperlancar aktivitas 
organisasi. Budaya organisasi yang kuat tidak serta merta akan berjalan dengan mudah, sehingga perlu ada penyesuaian didalamnya.

Organisasi dengan budaya yang kuat akan mempengaruhi perilaku dan efektifitas kinerja karyawan. Kinerja karyawan akan berjalan sesuai dengan budaya yang dianutnya dalam organisasi tersebut. Selain itu, penerapan budaya dalam suatu perusahaan juga akan membentuk karakter karyawannya dengan sendirinya dalam menjalankan tugasnya dan mencapai tujuan dari perusahaan.

\section{Pengaruh Iklim Organisasi terhadap Kinerja Karyawan}

Berdasarkan tabel 4 dapat dilihat bahwa nilai koefisien variabel iklim organisasi menunjukkan angka positif yaitu sebesar 0.477 dan nilai signifikan sebesar 0,002 nilai ini lebih kecil dari alpha $5 \%(0,002<0,05)$. Hal ini menunjukan $\mathrm{Ho}$ ditolak $\mathrm{Ha}$ diterima, artinya secara parsial terdapat pengaruh positif dan signifikan iklim organisasi terhadap kinerja karyawan.

Penelitian ini mendukung penelitian sebelumnya yang dilakukan Setiawan, Kiki Cahaya (2015), Murniaty, Dewi \& Yeni Absah (2013), Tantowi, Ridwan, \& Hesti Widi Astuti (2016) dan Radianto, Ari \& Sunuharyo, Bambang Swasto (2017) menemukan bahwa terdapat pengaruh signifikan iklim organisasi terhadap kinerja karyawan.

Penelitian ini juga diperkuat oleh pendapat Liliweri (2014:302) bahwa "iklim organisasi sangat mendukung kinerja karyawan dalam menjalankan kompetensinya untuk bekerja secara produktif". Dengan demikian iklim organisasi merupakan suatu nilai-nilai karakteristik dalam organisasi yang dapat membedakan organisasi satu dengan lainnya dan dapat mempengaruhi kinerja karyawan yang ada dalam organisasi tersebut.

Menurut Tagiuri dan Litwin (dalam Wirawan, 2008), iklim organisasi merupakan kualitas lingkungan internal organisasi yang secara relatif terus berlangsung, dialami oleh anggota organisasi dengan mempengaruhi perilaku mereka dan dapat dilukiskan dalam pengertian satu set karakteristik atau sifat organisasi. Iklim organisasi merupakan gambaran kolektif yang bersifat umum terhadap suasana kerja organisasi yang membentuk harapan dan perasaan seluruh karyawan sehingga kinerja karyawan meningkat. Iklim organisasi tersebut sangat mempengaruhi kinerja karyawan yaitu dengan menciptakan iklim organisasi yang sehat dalam perusahaan. Dengan demikian, para karyawan akan semakin bersemangat dan diharapkan dapat meningkatkan kinerja karyawan.

\section{KESIMPULAN DAN SARAN Kesimpulan}

Penelitian ini berisikan suatu model yang menguji pengaruh budaya organisasi dan iklim organisasi terhadap kinerja karyawan pada PT. Samudra Muara Enim Sumatera Selatan. Adapun kesimpulan penelitian ini sebagai berikut :

1. Secara bersama-sama terdapat pengaruh signifikan budaya organisasi dan iklim organisasi 
terhadap kinerja karyawan pada PT. Samudra Muara Enim Sumatera Selatan.

2. Secara parsial terdapat pengaruh positif dan signifikan budaya organisasi terhadap kinerja karyawan pada PT. Samudra Muara Enim Sumatera Selatan.

3. Ssecara parsial terdapat pengaruh positif dan signifikan iklim organisasi terhadap kinerja karyawan pada PT. Samudra Muara Enim Sumatera Selatan.

\section{Saran}

1. Penerepan budaya organisasi dan iklim organisasi pada PT. Samudra Muara Enim Sumatera Selatan sudah cukup baik sebagai acuan dalam bekerja. Diharapkan kedepannya, penerapan budaya organisasi dan iklim organisasi lebih ditingkatkan lagi agar benarbenar meresap dan dijiwai oleh setiap individu yang ada dalam perusahaan.

2. Disarankan untuk peneliti selanjutnya, diharapkan untuk menambah variabel lain yang dapat dijadikan indikator dalam penelitian lanjutan. Hal ini karena masih adanya variabel-variabel yang belum ditemukan penulis yang masih memiliki hubungan yang berkaitan dengan budaya organisasi, iklim organisasi dan kinerja karyawan.

\section{DAFTAR PUSTAKA}

Amanda, Enno Aldea. Budiwibowo, Satrijo. \& Nik Amah. 2017. Pengaruh Budaya Organisasi Terhadap Kinerja Karyawan di Pdam Tirta Taman Sari Kota Madiun. ASSETS Jurnal Akuntansi dan Pendidikan. Vol. 6 No. 1 HImn. 1-12
Bangun, Wilson. 2012. Manajemen Sumber Daya Manusia. Bandung: Erlangga.

Liliweri, Alo. 2014. Sosiologi dan Komunikasi Organisasi. Jakarta : Bumi Aksara

Murniaty, Dewi \& Yeni Absah. 2013. Pengaruh Iklim Organisasi Terhadap Kinerja Karyawan Bagian Pemasaran Pada Pt Telkom Divisi Telkom Flexi Medan. Jurnal Media Informasi Manajemen Fakultas Ekonomi Universitas Sumatra Utara. 1(3), 2013: h:1-10

Novziransyah, Nanda. 2017. Pengaruh Budaya Organisasi Terhadap Kinerja Karyawan PT. PLN (Persero) Kantor Wilayah Sumatera Utara Medan. Jurnal JUMANTIK Volume 2 nomor 1 , Mei 2017.

Pramudyo, Anung. 2010. Analisis Faktor-faktor yang Mempengaruhi Kinerja Dosen Negeri Dipekerjakan Pada Kopertis Wilayah V Yogyakarta jurnal.umy.ac.id/ index.php/ jbti/article/ view/ 1456/198.

Radianto, Ari \& Bambang Swasto Sunuharyo. 2017. Pengaruh Iklim Organisasi Dan Budaya Organisasi Terhadap Kinerja Karyawan (Studi pada Karyawan PT.PG Krebet Baru Malang). Jurnal Administrasi Bisnis (JAB)|Vol. 53 No. 1 Desember 2017.

Setiawan, Kiki Cahaya. 2015. Pengaruh Iklim Organisasi Terhadap Kinerja Karyawan Level Pelaksana di Divisi Operasi PT. Pusri Palembang. PSIKISJurnal Psikologi Islami Vol. 1 No. 1 (2015) 23-32. 
Sofyandi, Herman, 2012. " Manajemen Sumber Daya Manusia”. Penerbit Graha Ilmu, Yogyakarta.

Sutrisno, Edi. 2013. Budaya Organisasi. cetakanke-3 jakarta : Kencana Prenadamedia Group.

Tantowi, Ridwan, \& Hesti Widi Astuti. 2016. Pengaruh Iklim Organisasi Terhadap Kinerja Karyawan Pada PT. Bank Danamon Simpan Pinjam Unit Metro. Jurnal Bisnis Darmajaya, Vol. 02 No. 02, Juli 2016.

Tika, Moh. Prabundu 2010. Budaya Organisasi dan Peningkatan Kinerja Perusahaan. Cetakan ke2. Jakarta : Bumi Akasara.

Uha,I. Nawawi 2015. Budaya Organisasi Kepemimpinan dan
Kinerja. Jakarta: Kencana Prenada Media Group.

Wibowo, 2014. Manajemen Kinerja. cetakan ke-4.Jakarta : PT Raja Grafindo Persada.

Wirawan. 2008. Budaya dan Iklim Organisasi. Teori, Aplikasi dan Penelitian. Jakarta. Salemba Empat.

Zahriyah, Umi Wita. Hamidah Nayati Utami \& Ika Ruhana. 2015. Pengaruh Budaya Organisasi Terhadap Kinerja Karyawan (Studi Pada Karyawan PT. PLN (Persero) Distribusi Jawa Timur Area Malang). Jurnal Administrasi Bisnis (JAB)| Vol. 2 No. 1 Februari 2015. 